\title{
Література
}

1. Алиев Ю. Б. Настольная книга школьного учителя-музыканта / Юлий Багирович Алиев. М. : Гуманит. изд. центр ВЛАДОС, 2000. - 336 с. 2. Бочкарьов Л. Л. Проблема адекватності сприйняття музики / Л. Л. Бочкарьов // Музична психологія і психотерапія. - 2007. - № 3. 3. Выготский Л. С. Психология искусства / Лев Семенович Выготский. - М. : Искусство,1986. 320 с. 4. Кабалевский Д. Б. Педагогические размышления: избранные статьи и доклады /Дмитрий Борисович Кабалевский. - М. : Просвещение, 1986. - 336 с. 5. Талызина Н. Ф. Психология музыкальных способностей / Н. Ф. Талызина, О. П. Лобанова. - М. : Выс. шк., 2009. - 244 с. 6. Теплов Б. М. Пихология музыкальных способностей / Б. М. Теплов // Избранные труды в 2т. Т. 1. - М. : Педагогика, 1985. 7. Ткачова Н. П. Сприйняття музики у вихованні учнів загальноосвітньої школи. Теорія і методика мистецької освіти : [зб. наук. праць] / [Н. П. Ткачова ; ред. кол. О. П. Щолокова та ін.]. - К. : НПУ, 2000. - 181 с.

УДК 811.161.2(07)

Л. С. Цоуфал,

старший викладач,

Криворізький педагогічний інститут ДВНЗ «Криворізький начіональний університет»

\section{ВИДИ ВПРАВ ДЛЯ ПІДГОТОВКИ УЧНІВ ДО НАПИСАННЯ ТВОРІВ}

Цоуфал Л. С. Види вправ для підготовки учнів до написання творів.

У статті охарактеризовано твір як вид роботи з розвитку зв'язного мовлення, визначено види вправ для розосередженої підготовки учнів до написання творів.

Ключові слова: писемне мовлення, твір, види творів, підготовка до написання твору.

Цоуфал Л. С. Виды упражнений для подготовки учащихся к написанию сочинений.

В статье охарактеризовано сочинение как вид работы по развитию связной речи, определены виды упражнений для рассредоточенной подготовки учащихся к написанию сочинений.

Ключевые слова: письменная речь, сочинение, виды сочинений, подготовка к написанию сочинения.

Tsoufal L. S. Types of exercises to prepare students for writing essays.

The article described the composition as a form of work for the development of coherent speech, identify che tupes of exercises to prepare students dispersed to writing essays.

Key words: writing, essay, types of essays, preparing to write essays.

У сучасних умовах розвитку шкільної мовної освіти особливої актуальності набуває проблема формування в учнів умінь і навичок діалогічного й монологічного мовлення, оскільки успішність людини в задоволенні практичних потреб, реалізації професійних планів значною мірою залежить від здатності до ефективної комунікації. Метою навчання мови відповідно до замовлення суспільства $є$ виховання всебічно розвиненої, духовно багатої особистості, яка володіє уміннями і навичками вільно, комунікативно виправдано користуватися засобами рідної мови - іiі стилями, типами, жанрами в усіх видах мовленнєвої діяльності.

У чинній програмі з української мови для 5-9 класів, зокрема в мовленнєвій змістовій лінії, серед робіт з розвитку зв'язного мовлення чільне місце посідають твори - вид вправ, який передбачає самостійний виклад учнями думок, почуттів, суджень. У порівнянні 3 переказом твір - складніший вид роботи, оскільки передбачає створення висловлювання за певну тему без опори на текст-зразок, вимагає від учнів самостійності, активності, вираження в тексті особистого життєвого досвіду. Твір сприяє не лише реалізації навчальної, розвивальної, виховної функцій мови, а й підготовці учнів до активної комунікативної діяльності в різноманітних ситуаціях.

Як зазначає Т. Донченко, в учнівському творі виявляється все: мовленнєвий розвиток учнів, знання властивостей гарного мовлення, словниковий запас учня, володіння 
нормами, фразеологією й виразними засобами мови, орфографічно-пунктуаційна грамотність, уміння змістовно, логічно, послідовно викладати зміст, загальний розвиток школяра, начитаність, його виховання, уподобання, спостережливість та ін. [1, с. 2]. Твір виявляє вміння його автора користуватися мовними засобами під час мовленнєвої діяльності відповідно до стилю, жанру та комунікативної мети.

Питаннями навчання учнів створювати писемні висловлювання опікувалися такі дослідники: О. Біляєв, Т. Донченко, І. Зимня, С. Караман, Т. Ладиженська, М. Львов, Г. Михайловська, М. Пентилюк, М. Стельмахович та інші. У методичному доробку науковців наявні рекомендації щодо навчання творів на уроках мовленнєвого розвитку, однак подальшого розроблення потребує проблема розосередженої підготовки школярів до створення текстів. Аналіз наукових джерел та спостереження за навчально-виховним процесом дозволяють стверджувати, що система роботи з удосконалення монологічного мовлення повинна містити вправи і завдання, розраховані на постійне залучення учнів до активних форм спілкування, сприяти розвитку їхньої комунікативної компетенції.

Meта cmammi - охарактеризувати твір як вид роботи з розвитку зв'язного мовлення, визначити ефективні види вправ, спрямовані на підготовку учнів до написання творів.

Основним змістом роботи з розвитку мовлення в школі $\epsilon$ розвиток умінь створювати текст, що формуються під час цілеспрямованого навчання, яке буде успішним лише за умови використання зв'язних висловлювань з комунікативною метою. Роль писемного мовлення в житті сучасної людини визначається необхідністю фіксації отриманої інформації, конспектуванням різноманітних джерел, створенням власних висловлювань, тому вдосконалення писемного монологічного мовлення учнів - надзвичайно важливий напрям діяльності вчителя.

Письмо як вид мовленнєвої діяльності має певну структуру, знання якої допоможе вчителю правильно організувати процес формування мовленнєвих умінь і навичок школярів.

1. Етап попереднього орієнтування. На цьому етапі той, хто пише, визначає, 3 якою метою, кому і що він буде писати.

2. П Планування діяльності (планується не тільки зміст, а й форма мовлення).

3. Реалізація процесу письма. В умовах писемної форми спілкування відсутній безпосередній реципієнт і проміжний зворотній зв'язок. Той, хто пише, не бачить реакції того, хто читає, на кожну фразу. У писемному мовленні не задіяні невербальні засоби спілкування (міміка, жести), що посилює вимоги до змісту писемного мовлення.

4. Контроль мовленнєвої діяльності (перевіряється форма і зміст написаного) [5, c. 296].

Зважаючи на специфіку писемного мовлення, значну увагу в процесі навчання учнів необхідно звернути на фази планування, реалізації й контролю.

У роботі над творами немає єдиного підходу, у ній допускається велика кількість методично обгрунтованих варіантів навчання, зумовлених різними чинниками, зокрема видовою класифікацією творів. Нині науковці, керуючись різними критеріями, визначають такі види творів:

а) за метою проведення - навчальні й контрольні;

б) за формою - усні й письмові;

в) за місцем виконання - класні і домашні;

г) за ступенем самостійності учнів у виконанні роботи - колективні й індивідуальні;

г) за джерелами матеріалу - на лінгвістичні теми, на основі власних спостережень, на основі почутого або прочитаного, за картиною, за серією малюнків, діафільмом, кінофільмом, телепередачею;

д) за складністю - за опорними словами і словосполученнями, 3 додатковими завданнями;

е) за способом викладу думок (типом мовлення) - розповідь, опис, міркування;

є) за стилем - художні, публіцистичні, наукові; 
ж) за обсягом - розгорнуті твори, твори-мініатюри.

У роботі над твором активізуються всі види мовленнєвої діяльності, тому правомірно говорити про комплексний характер навчання зв'язного мовлення, що забезпечує тісний зв'язок лінгвістичної теорії з мовною практикою.

Монологічне мовлення, зауважує Т. Донченко, містить три якісно відмінних компоненти, які відображають різноманітні його сторони: змістову, логіко-композиційну й мовну. Організовуючи підготовку до твору, важливо приділити увагу вдосконаленню кожного з цих боків монологічного мовлення учня, його індивідуального стилю [1, с. 2].

Твір має велике дидактичне й виховне значення, оскільки вимагає від учнів активізації мовних знань, мобілізації мовленнєвих умінь і навичок, зосередженого осмислення певної теми. Робота над виконанням цього виду творчого завдання сприяє розвитку мислення учнів, формуванню світогляду та моральних переконань, підвищенню рівня культури мовлення.

Т. Ладиженська виокремлює уміння, які формуються у школярів у процесі навчання писати твори: вдумуватися в тему, осмислювати іiі межі, розкривати тему твору; підпорядковувати свій твір певній (основній) думці; збирати матеріал для твору; систематизувати матеріал, групувати і визначати послідовність подачі матеріалу в творі; будувати твір у певній композиційній формі; правильно і гарно висловлювати свої думки; виправляти, змінювати, удосконалювати написане [3, с. 13-16].

Труднощі, з якими стикаються учні під час написання творів, спричинені відсутністю або недостатністю підготовчої роботи. Без продуманої підготовчої роботи формування вмінь монологічного мовлення відбувається безсистемно, майже самоплинно, «учень йде до мети, не усвідомлюючи, з чого складається його робота над твором, які навички йому знадобляться, яких знань і вмінь у нього ще немає і як їх набути. Це в свою чергу веде до того, що виконання такого завдання стає для учня складним» [1, с. 3].

Організовуючи роботу над творами, необхідно враховувати психологічні чинники, що стимулюють діяльність учнів і активізують творчі здібності, найважливішим із яких $\epsilon$ мотив. Позитивна мотивація забезпечує ефективність виконання комунікативного завдання, спонукає до усвідомленого навчання і самовдосконалення.

Якісний i кількісний показник словникового запасу людини $\epsilon$ важливою комунікативною ознакою мовлення. Тому, на нашу думку, у процесі розосередженої підготовки учнів до написання творів необхідно особливу увагу приділяти словниковій роботі, спрямованій на збагачення мовлення школярів, засвоєння слів у всій різноманітності їх значень, встановлення системних відношень між словами, добір виражальних засобів для створення висловлювання на певну тему. Бідний словник, відсутність теоретичних знань лінгвістичної теорії, недостатній рівень оволодіння мовленнєвими поняттями і мовними нормами заважають учням створювати монологічні висловлювання. Окрім того, типовими недоліками творчих робіт школярів є недостатнє розуміння теми, невміння логічно, послідовно розкрити головну думку, обгрунтувати висловлені думки.

Успішна реалізація завдань мовленнєвого розвитку школярів можлива лише за умови систематичної і цілеспрямованої роботи над збагаченням їх словникового складу, удосконаленням граматичної будови мовлення, формування умінь розрізняти типи і стилі мовлення, надавати висловлюванню відповідного стилістичного й емоційного забарвлення, адекватно сприймати, відтворювати і створювати висловлювання.

Відповідно до основних напрямків роботи над мовними засобами в аспекті розвитку мовлення А. Купалова визначає такі види вправ:

1. Аналіз готового матеріалу (спостереження за питаннями та завданнями, розпізнавання та добір потрібних елементів, порівняння подібних явищ мови).

2. Перетворення поданого мовного матеріалу (мовний експеримент, синонімічні заміни мовних фактів, побудова різноманітних мовних одиниць за опорними моделями, схемами, розширення або скорочення матеріалу, редагування). 
3. Створення висловлювання (вибір мовних засобів у співвідношенні 3 темою, конструювання елементів твору, написання твору на пропоновану чи самостійно сформульовану тему у визначеному стилі) [2, с. 16].

Підготовка до твору, яка розосереджено здійснюється на аспектних уроках, може передбачати використання дидактичного матеріалу на соціокультурну тему, подібну до наступного твору, задля осмислення учнями змісту висловлювання, систематизації тематично об'єднаної лексики, збагачення мовлення необхідними для створення тексту мовними засобами. Належна увага до завдань, спрямованих на підготовку учнів до написання творів, дозволяє попередити як мовні, так і мовленнєві (лексичні, граматичні і стилістичні) помилки.

Організовуючи опрацювання навчального матеріалу, розробляючи систему вправ, учитель керується тим, яку роль має виконати кожна 3 них у процесі збагачення i вдосконалення мовлення учнів. Словесник має враховувати, що становлення навичок мовлення проходить такі етапи:

1) сприймання i репродуктивне відтворення мовних засобів (вправи в основному аналітичні - класифікаційні і вибіркові);

2) формування вмінь будувати і вживати мовні засоби (вправи конструктивні);

3) формування вмінь добирати мовний матеріал, необхідний для вираження певного змісту (мовленнєві вправи);

4) використання засвоєного мовного матеріалу в непідготовлених висловлюваннях (комунікативні вправи) [4, с. 29].

Отже, вправи на використання мовних одиниць різних рівнів у формулюванні учнями своїх думок, на аналіз текстів різних стилів, виконання ситуативних завдань, редагування чужих і власних писемних висловлювань мають посісти вагоме місце в загальній системі розвитку мовлення школярів.

Перспективи подальших досліджень убачаємо в розробленні системи вправ для навчання учнів письма як виду продуктивної мовленнєвої діяльності, які можуть бути використані під час опрацювання граматичного матеріалу на уроках української мови в середній школі.

\section{Література}

1. Донченко Т. Учнівські твори як засіб мовленнєвого розвитку учнів / Тамара Донченко // Українська мова і література в школі. - 2009. - № 1. - С. 2-7. 2. Купалова А. Ю. Типология упражнений // Методика развития речи на уроках русского языка / А. Ю. Купалова, Н. Е. Богуславская, В. И. Капинос и др. / под. ред. Т. А. Ладыженской. - [2-е изд.]. - М. : Просвещение, 1991. - С. 15-17. 3. Ладыженская Т. А. Система обучения сочинениям на уроках русского языка (IV-VIII классы) / Т. А. Ладыженская. - М. : Просвещение, 1978. - 367 с. 4. Мельничайко В. Я Творчі роботи на уроках української мови: Конструювання. Редагування. Переклад [посіб. для вчит.] / Володимир Ярославович Мельничайко. - К. : Рад. школа, 1984. 223 с. 5. Методика навчання української мови в середніх освітніх закладах / Кол. авторів за ред. М. І. Пентилюк: М.І.Пентилюк, С. О. Караман, О.В.Караман, О. М. Горошкіна та ін. - К. : Ленвіт, 2004. - 400 с. 6. Синиця І. О. Особливості мовного оформлення учнями своїх думок / I. О. Синиця // Українська мова і література в школі. - 1976. - № 3. - С. 61-66. 